SHS Web of Conferences 2, 00016 (2012)

DOI: $10.1051 /$ shsconf $/ 20120200016$

(C) Owned by the authors, published by EDP Sciences, 2012

\title{
Children's Palliative Care in Latvia and its relation to improvement of Quality of Life of the families with incurably ill children
}

\author{
A. Jansone \\ Rīga Stradinš University, Latvia
}

\begin{abstract}
In Latvia's health care sector children's palliative care (PC) is comparatively new branch. There are relatively few scientific researches performed in PC by now. This can be explained by demographical and academic factors as well as by specific ethical problems. The Palliative Care Service at Children's University Hospital is the only service of the kind in Latvia providing both - in-patient and home PC service for patients residing in Riga and Riga district. The service is not available to every child in all regions of Latvia. Hence, the main objective for the future would be establishing a high-quality, assessable children's PC service system throughout the country. The specialists of the children's PC team have launched an initial nation-wide research on quality of life of families with incurably ill children. The research on quality of life (QOL) in families with incurably ill children is essential in order to promote political decision-making in the government and in the private sector regarding health-care including development and improvement of children's PC in Latvia. Results of the research on QOL of the families with incurably ill children will set base for improvement and perfection of service provided by PC team.
\end{abstract}

Key words: children's palliative home care, quality of life

Palliative care is active, all-embracing care about children (and their family members) with progressive chronic diseases - those for whom possibilities of radical treatment are exhausted. It aims at provision of the best possible quality of life for patients and their family members. The care comprises pain and other symptom control, meeting patient's psychological, social and spiritual needs, which would allow the patient to feel comfortably to the utmost (Goldman, Hain, Liben, 2006; 6).

Quality of life is a well-being index of a person, family, group of people or the society, which includes bodily and mental health, leisure time and its usage, work, ties with the society, right of independent decision-making and implementation, as well as material well-being (Sociālo pakalpojumu un sociālās palīdzības likums, 1. nodalasas, 1.pants). In scientific publications quality of life is regarded as a multidimensional concept. It is derived from the World Health Organisation definition, which describes health as physical, social, emotional and spiritual well-being, rather than just absence of the ailment (Koot, Wallander, 2001; 4). As worldwide statistics testifies, the number of patients who need $\mathrm{PC}$ is growing. The scientific research on PC is rather scarce, even globally, which could be explained with demographic and academic factors, as well as specific ethical problems. There is a rather small number of researches on quality of life of incurably ill children and their family members, and the factors it is affected by, mentioned in the literature. Methods that would allow to precisely and reliably measure/study quality of life in families with incurably ill children are being developed and improved continuously (Doyle, Hanks, 1999; 86). In recent years, PC necessity assessment has been carried out in various countries. It has provided valuable information on the mortality rate and place of death, as well as on exploration of needs of the children, families, carers and service providers. PC is based on a holistic (or all-embracing) care model that perceives the human being as the entity of all the individual's existence dimensions. There are four dimensions distinguished in the model: somatic, social, psychoemotional and spiritual. Disturbances in any dimension cause disturbances in others, therefore the

This is an Open Access article distributed under the terms of the Creative Commons Attribution License 2.0, which permits unrestricted use, distribution, and reproduction in any medium, provided the original work is properly cited. 


\section{SHS Web of Conferences}

PC team consists of specialists of all the aforementioned spheres. Each of the multidisciplinary team professional (physician, nurse, social worker, chaplain, psychotherapist) has their own important role in the work of the team, both in individual work with the patient and planning and organising the work of the team in order to render the most appropriate service to the family and achieve improvement in their quality of life (Goldman, 1998; 214). Receiving a holistic support, the stress-caused psychological harm as well as that hampering work organisation are diminished for the family. The psycho-emotional condition of the family members would improve, as the core of children's PC is improvement of quality of life for the patient and his/her family members.

So far, there has not been established a unified care system about children with incurable diseases that would include medical, psychological, social and spiritual care about the child and his/her family members during the course of the ailment and support to the relatives in bereavement - in the time of mourning. The only complete multidisciplinary PC team is operating in Children's University hospital in Riga. It provides in-patient and out-patient consultative assistance to all families. Multidisciplinary team also provides children's PC home service only to families living in Riga. Children's home PC service is available 24 hour $/ 7$ days per week/ 365 days per year. Every year number of home care patients is growing. In 2010, 143 patients and their family members received home care service.

Research performed during 2005-2010 on QOL of families with incurably ill children provides significant information on families' life quality in dynamics, opens possibility for PC professionals to analyse and improve home care service basing on families' needs.

Objective of the work: Investigate the dynamics of the main quality-of-life hampering factors in families with incurably ill children who have received palliative home care service.

\section{Materials and methods}

A qualitative, longitudinal research carried out in 2005 involved 10 families with incurably ill children receiving PC care service as well as 5 families in mourning, whose children had passed away during the last 12 months. In 2008 and 2010 the follow-up inquiry of these families was carried out. Families were inquired by using questionnaire. By set-up, the questionnaire was semi-structured and open, partially open and closed questions included thus allowing to obtain information on the psycho-social portray of the family, inter-family relations and main stress factors.

The age range of the children was from 1 to 18 years. Diagnoses of children included an incurable organ abnormality, haemato-oncologic diseases, progressive chronic CNS pathology.

\section{Results}

When performing the survey in 2005, in all the questioned families with incurably ill child changes in family psycho-emotional homeostasis were observed, for parents carrying about an incurably ill child on a long-term basis fall into social isolation by losing their job, professional skills and friends.

Situation of family with incurably ill child is precisely described by mother A saying: "Family with incurably ill child is forced to renounce from many things: from improving living conditions (not able to take a loan in bank), from studying and obtaining additional education (since child care requires majority of time), from searching for better paid job (frequent sick leaves). In the light of above mentioned it can be said that situation in family is bordering on hopelessness."

During the course of the child's disease, at least one of the family members is forced to take a continuous leave of care. In 9 families one family member - mother - is forced to be on lasting parental leave. It is essential to remark that in 7 families the financial situation grew worse with the child having fallen ill, and in mere 3 families it had not changed. The parents pointed out in the questionnaire, in $75 \%$ cases the financial responsibly lays on the father, in $8.3 \%$ cases - on the mother, in $16.7 \%$ cases on another family member. The average monthly income per capita added up to LVL 93.90. 9 out of 10 children did not need hospitalisation during the period of the research. 
Int. Conf. SOCIETY. HEALTH. WELFARE; Congr. of Rehabilitation Doctors of Latvia

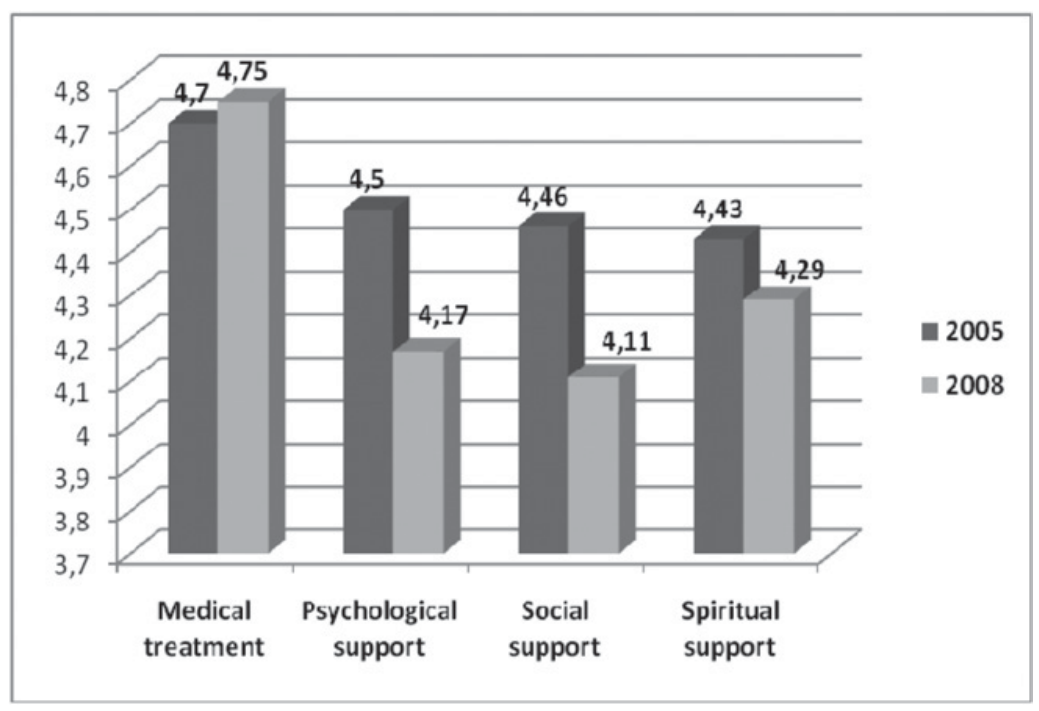

Figure 1. PC service evaluation by families /average/ years 2005 and 2008.

In 2008, only 5 families continuing receiving home care service have been questioned. In 4 families child has passed away, for one child PC service was not any more necessary due to health improvement. Results of the 2008 questioning testify, in 3 families the financial situation has improved. In 3 families, the mother has re-entered the labour market. The monthly income per capita has grown to LVL 200. Mere 2 families indicated deterioration of the financial situation. Responsibility for the psychological support, spiritual care and consolation still mainly lies on the mother. Compared to the 2005 questioning results, mutual communication and psycho-emotional stability in the families have improved. Another positive change is that in all families parents openly speak about their child's disease and express their feelings and beliefs.

As results of the 2005 and 2008 research indicate, the parents primarily appreciate $24 \mathrm{~h}$ a day, 365 days a year availability of PC. The parents have thorough information and understanding about possible reception of palliative care from the PC service, which is confirmed by the questioning results. Support of the PC team professionals is noted as highly necessary and required in answers of all the respondents. Significance of help provided by PC team professionals is described by quotation by mother L: "It is tremendous help for the family to receive professional support in the moments when lacking advice, physical and spiritual strengths, including situations when parents are exhausted and unwell." All the questioned families in 2005 and 2008 have rated the medical and psychological support as the most essential, especially during crises. Professional medical care was rendered at home - in the environment where the child feels most comfortable. In 90\% questionnaires parents have stressed feeling safe and confident about the palliative care team: "Sense of security, possibility to relay on PC team professionals", "There is no running around from one specialist to another". $80 \%$ parents have stressed significance of social and spiritual care." PC service evaluation by questioned families /average/ years 2005 and 2008 shown in Figure 1 (in 5 grade scale):

The obtained data demonstrates necessity of holistic care about the family both during the course of the child's illness and at the time of passing away.

In 2005, 5 grieving families were questioned and in 2008 - 6. The most necessary support for grieving families was medical support provided to child during the course of illness and at the time of passing away. Availability to receive help at any time at home was essential for all mourning families: "Child doesn't have to survive crisis in hospital environment, instead care can be receive at home with the same effectiveness." All the questioned mourning families stressed importance and necessity of 


\section{SHS Web of Conferences}

psychological and spiritual care: "To understand how to live wholesome life in these difficult situations and afterwards". Parents accented the sense of security as important feeling, possibility to relay on PC team professionals. During the research we clarified expectations of grieving families:

1. To provide more spiritual and psychological support;

2. To pay special attention to family members after child's death, even in situations where family has expressed refusal at first;

3. To repeat information on progress of the care process to the family;

4. To develop further availability of home PC services.

In 2010 questioning of 4 families continuing receiving PC service at home was carried out. Results were compared to the ones from the previous years to evaluate dynamics of families' QOL in the period of 2005-2010.

Family No 1 has improved interaction with community and family's integration in social environment has become deeper. Inter-family relations and couple's relationships improved. Family has become more cohesive. Family recognises and accepts reality, speaks openly on topics of child's illness and death. Mother re-integrated in labour market. Financial situation of family improved.

Family No 2 has improved interaction with community and family's integration in social environment has become deeper. Inter-family relations and couple's relationships improved. Family has become more cohesive. Performing of social roles improved in family. Mother has started studies to obtain higher education, re-integrated in labour market. Financial situation of family improved. The second child is born in family - a healthy child. Family speaks openly on topics of child's illness and death.

Family No 3 is single-parent family, shares household with grandmother. The second child is born in family - a healthy child. Financial situation of family worsened. Mother's role in family - responsibility for family's well-being, psychological and spiritual balance, childcare. Inter-family relations are poor. Family doesn't speak openly on topics of child's illness and death.

Family's No 4 interaction with community has improved. Mother has started studies to obtain higher education and re-integrated in labour market. Financial situation of family improved. Inter-family relations and couple's relationships grown worse. Family speaks openly on topics of child's illness and death.

Family's interaction with community is shown in the Figure 2.

Income per family member per month (LVL) show in the Figure 3.

During research we investigated perception and opinion of these 4 families towards service provided by multi-disciplinary PC team. Parents in their answers are stressing necessity for all of team's professionals involvement in care process:

- "This is availability of immediate and qualitative medical treatment in home environment, performing of different procedures and manipulations. Also possibility to receive 24 hours telephone consultations, which is especially important during week-ends, holidays as well as in crisis moments."

- "Along with medical treatment, availability of psychological support during crisis in forms of different individual consultations and parent support groups is important for family. This gives opportunity to review values of life with desire to raise quality of life for the individual and family as whole."

- "Psychological support is very important. In most cases bystanders can do nothing to help since they can not truly understand the situation and family has a felling that everyone is avoiding contacts with them."

- "Social support is based on providing information on availability of different social services, help with solving family problems related to financial situation and social care."

- "Spiritual support means to encourage thinking about eternal and imperishable values. It helps not to loose desire to live, gives hope, assists in maintaining willpower and ability to enjoy life in spite circumstances. Not to loose faith in good." 
Int. Conf. SOCIETY. HEALTH. WELFARE; Congr. of Rehabilitation Doctors of Latvia

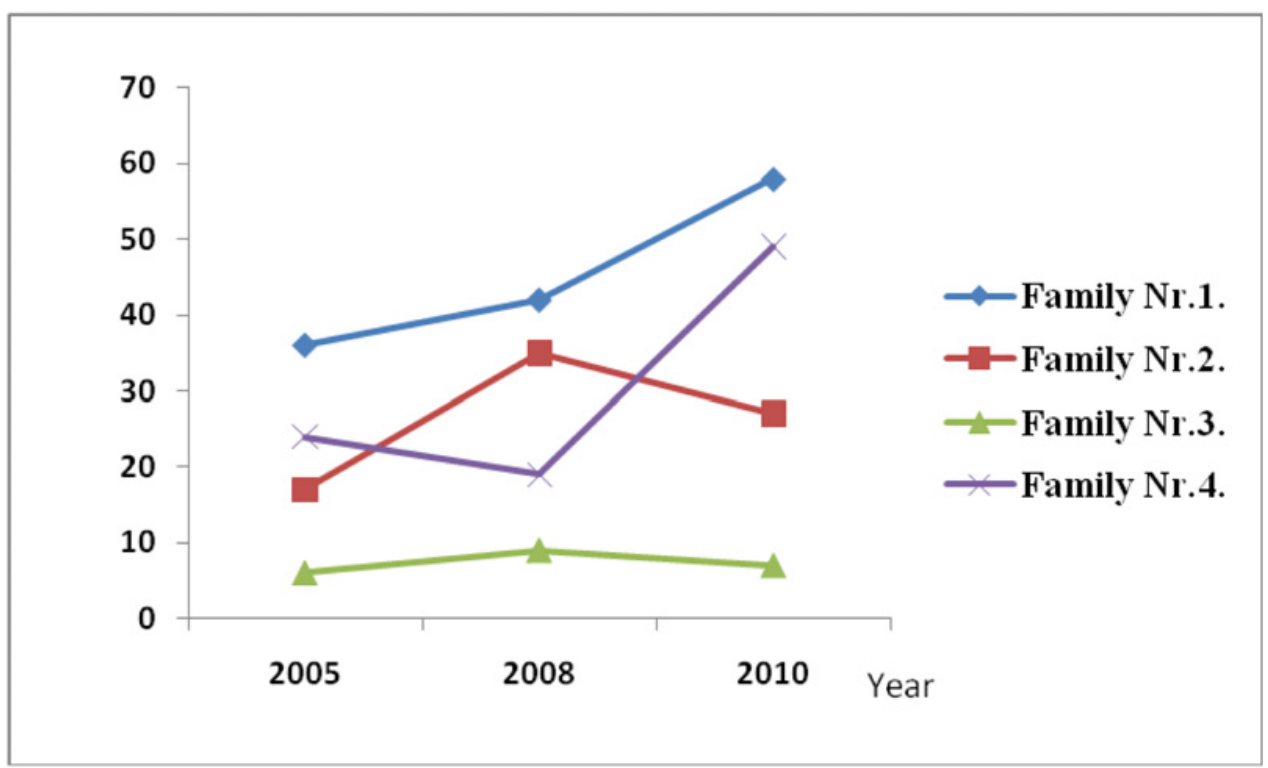

Figure 2. Family's interaction with community.

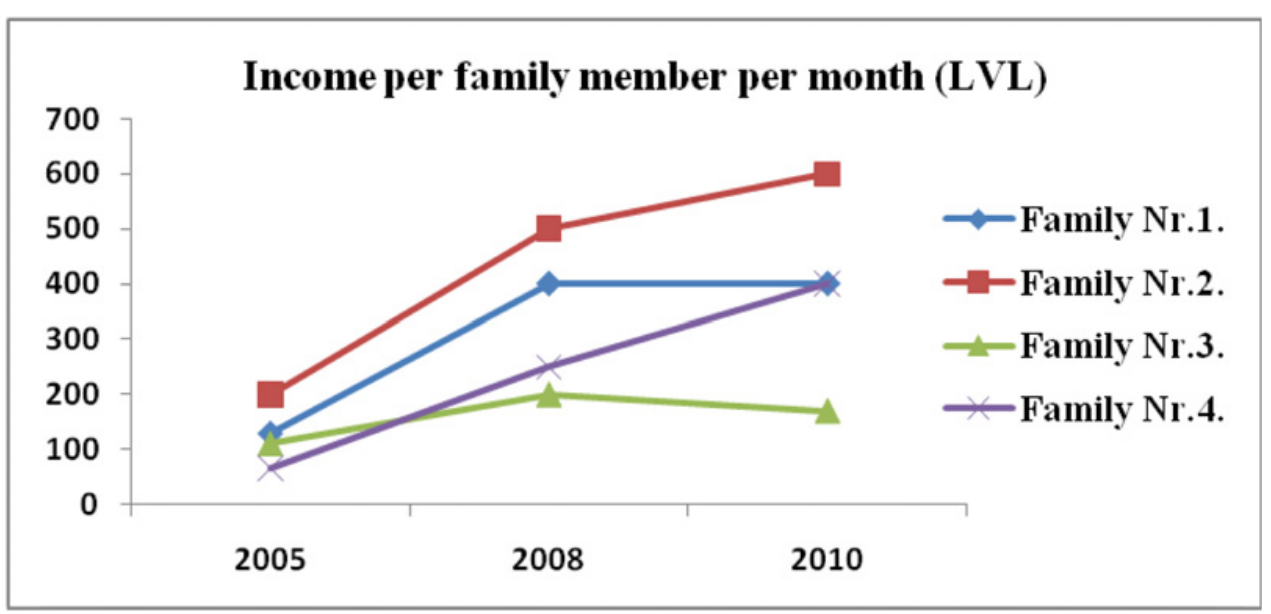

Figure 3. Income per family member per month (LVL).

\section{Discussion}

When analysing the survey results, it was observed that the families had been undergoing a continuous social, psychological, emotional and spiritual stress resulting in increased risk of the burn-out syndrome and eventual psychological crisis. It should also be noted that family's communication (social relationships and contacts) with the community it belongs to diminishes. During the course of the child's disease, at least one of the family members is forced to take a continuous leave of care. A risk exists that the other parent experiences increased emotional strain and stress. He/she is forced to enhance his/her labour performance (bringing about a psychosocial burden) in order to furnish the family. In $90 \%$ families mother cares about the ill child. Relatively infrequently - in mere $10 \%$ cases - other family 


\section{SHS Web of Conferences}

members or babysitters are involved. It proves insufficient social support. Care situation of a seriously ill and dying child is determined by his/her carers; besides, the amount of required care increases from day to day and its quality greatly depends on the bodily and emotional well-being of the carer. Thus, it is of importance that family members could be able to express their emotions and receive support. It should also be taken into account that parents have to cope with their own emotional hardship, which frequently results in different psychosomatic ailments, conflicts between the spouses, financial strains and employment problems. In case of the child's illness the parents experience unwonted stress and state of permanent crisis. In such a situation, it is important to help them find a psychological and spiritual balance between the needs of the ill child and the other family members. It is essential to provide a quality PC service to the family in such a situation by rendering medical, psychological, social and spiritual care. As the survey results indicate, professional support of each palliative care team member in various situations is of equal importance. Thanks to the psychological, spiritual and social support rendered by the team, families have been able to overcome crises, preserve partnership in the family and re-integrate in the labour market.

The survey confirmed the engrained stereotype of our society and culture that it is mother who has to take responsibility about care for the ill child. In families with a palliative ill child one of the parents usually does not work, which tells upon the financial situation of the family. A palliative ill child has specific needs and care about him/her requires substantial and regular financial investments. The average estimate of expenses on medication, special tube nutrition mixtures and sanitary goods calls for LVL 200 monthly per child. The research results prove necessity of the social policy and support improvement for PC patients and their families.

\section{Conclusions}

The obtained data conclude that quality of life is substantially aggravated by a continuous family crisis related to the incurable disease of the child that requires permanent care from the family members, sometimes for years, and brings about social isolation. A lasting financial crisis causes reduced quality of life of the family. The research result analysis proves necessity for the children's PC service and the multidisciplinary children's PC team. The parents' answers to the question about their wishes while receiving PC service demonstrate the parents clearly perceive the significance, objectives and goals of PC services in improvement of the family quality of life, while drawing attention to necessity for better accessibility of certain PC, regular dissemination of information and establishment of a special children's PC centre. Lasting, all-embracing support, including boosting the motivation for reintegration in the society and labour market, is necessary in order to help the family, which could be provided by a professional multidisciplinary children's PC team. The children's PC research results are a substantial proof of necessity of children's PC service development in the country, making it accessible throughout the country. There is no unified legislation in our country at the time being that would regulate provision and accessibility of children's PC service (guaranteed, accessible, paid-up). The service is not accessible to every child in every region. Thus, the main objective for the future would be accomplishment of in-depth, specific research on quality of life of incurably ill children, which would justify necessity of accessible, quality children's PC service in our country.

\section{References}

[1] Doyle, D., Hanks, G.W.C., MacDonald, N. (1999) Oxford Textbook of Palliative Medicine. UK: second edition, Oxford University Press.

[2] Eiser, C. (2004) Children with Cancer: The Quality of Life. Mahwah, New Jersey: Lawrence Erlbaum Associates.

[3] Goldman, A. (1998) Care of the Dying Child. Oxford: Oxford University Press. 
Int. Conf. SOCIETY. HEALTH. WELFARE; Congr. of Rehabilitation Doctors of Latvia

[4] Goldman, A., Hain, R., Liben, S. (2006) Oxford Textbook of Palliative Care for Children. Oxford: Oxford University Press.

[5] Higginson, I. (1995) Clinical Audit in Palliative Care. Oxford and New York: Radcliffe Medical Press.

[6] Koot, H., Wallander, J. (2001) Quality of Life in Child and Adolescent Illness: Concepts, Methods and Findings. East Sussex: Brunner-Routledge.

[7] Twycross, A., Moriarty, A., Tracy, B. (1998) Paediatric Pain Management: A Multi-disciplinary Approach. Oxon: Radcliffe Medical Press.

[8] Walsh, D. (2009) Palliative Medicine. Philadelphia: Sounders Elsevier.

[9] Stratēğiskās analīzes komisija. (2006) Dzīves kvalitāte Latvijā [Quality of Life in Latvia]. Rīga: Apgāds "Zinātne".

[10] Association for children with life-threatening of terminal conditions and their families (ACT) and Royal College of Paediatrics and Child Health (RCPCH) (1997). A guide to the development of Children's Palliative Care Services, p. 43.

[11] Council of Europe (2005). Recommendation Rec (2003) 24 of the Committee of Ministers to member states on the organisation of palliative care. Adopted by the Committee of Ministers on 12 November 2003 at the 860th meeting of the Ministers' Deputies Council of Europe.

[12] Sociālo pakalpojumu un sociālās palīdzības likums, 1. nodaļas, 1.pants [Social Services and Assistance Law]. http://www.likumi.lv/doc.php?id=68488 